2021 • Spring - Bahar • Volume - Cilt: 12 • Issue - Say1: 45

\title{
Investigation of the Factors Affecting the Attitudes of Academicians Towards Project Development to Enhance Innovation*
}

Duygu FINDIK COŞKUNÇAY, Atatürk University, Faculty of Economics and Administrative Science, Asst. Prof. Dr., duygu.findik@atauni.edu.tr, (D) 0000-0002-8932-5615

Şule ERDILMEN OCAK, Atatürk University, Project Development and Coordination Office, Instructor, s.erdilmen@atauni.edu.tr, (DD) 0000-0002-0886-2823

ABSTRACT Economic development can be achieved through knowledge-based growth. In this respect, universities have a significant role to produce knowledge and contribute innovation management through their research and development activities. However, too many obstacles bring difficulties on academicians to develop projects to increase innovation capabilities of the countries. The aim of this study is to identify the factors affecting attitudes of academicians towards research and development projects. In this study, an attitude scale and a structural model were developed to identify the key factors. According to the consequences obtained, perception of selfworth, perceived self-efficacy, reputation, anxiety, team interaction and justice factors directly and significantly affect academicians' attitudes towards project development. It is envisaged that identification of the factors affecting academicians' attitudes towards project development leads to rethink the obstacles of universities to become targeted innovative and entrepreneurial universities, contributing the enhancement of innovation, and produce projects that support the country's economy and solve social problems.

Keywords : Innovation, Innovation Management, Research and Development Projects

\section{İnovasyon Artımı İçin Akademisyenlerin Araştırma ve Geliştirme Projesi Geliştirmeye Yönelik Tutumlarını Etkileyen Faktörlerin Belirlenmesi}

ÖZ

Ekonomik gelişme bilgiye dayah büyüme ile sağlanabilir. Bu bağlamda, üniversiteler araştırma ve geliştirme faaliyetleri aracılı̆̆gyla bilgi üretme ve yenilik yönetimine katkı sağlama konusunda önemli bir role sahiptir. Ancak, birçok engel,

\footnotetext{
*An abstract version of this article was presented at the 39th Operations Research / Industrial Engineering National Congress, İstanbul, Turkey, July 5-7.

"This study was supported by the Scientific Research Projects Coordination Unit of Atatürk University with the SBA-2018-6339 project ID, 07.02.2019.
} 
akademisyenlerin ülkelerin inovasyon yeteneklerini artırmaya yönelik projeler geliştirmelerinde zorluklar yaşamasına neden olmaktadır. Bu çalısmanın amacı, akademisyenlerin araştırma ve geliştirme projelerine yönelik tutumların etkileyen faktörleri belirlemektir. Bu çalışmada, temel faktörleri belirlemek için bir tutum ölçeği ve yapısal bir model geliştirilmiştir. Elde edilen sonuçlara göre, öz-değer algısı, algılanan öz yeterlilik, itibar, kaygl, takım etkileşimi ve adalet faktörleri akademisyenlerin proje geliştirmeye yönelik tutumlarmı doğrudan ve önemli derecede etkilemektedir. Akademisyenlerin proje geliştirmeye yönelik tutumlarm etkileyen faktörlerin tespit edilmesi ile, üniversitelerin hedeflenen yenilikçi ve girişimci üniversiteler olmalarmın önündeki engelleri yeniden düşünmeye, yenilikçiliğin artmasına katkı sağlamaya, ülke ekonomisini destekleyen ve toplumsal sorunları çözen projeler üretmeye yol açacağı öngörülmektedir.

Anahtar : Inovasyon, Inovasyon Yönetimi, Araştırma ve Geliştirme Projeleri

\section{Kelimeler}

\section{INTRODUCTION}

The most powerful economies of the twenty-first century can be said to belong to countries that produce strong science and technology in the light of scientific research (Korkmaz, Şahin and Yeşil, 2011). Universities constitute a significant subsystem that produce information in regional innovation systems (Autio, 1998; Cooke, 2002). Considering that knowledge is the primary source for academicians to increase competitiveness, research and development (R\&D) projects can be said to have an important place for universities and academicians. In this context, it is important for the innovative policy approach that universities take an active role with scientific $R \& D$ projects in the industrial-science ecosystem.

As we look for ways to improve the transitions from science to innovation, much of the attention in academic literature and politics has sought to find critical success factors on the scientific side (Veugelers, 2014). Governments are increasingly aiming to be incorporated academic research into knowledge based growth more directly and on a wider scale. Modern societies try to overcome the barriers to raising people who can think scientifically by evaluating attitudes and behaviours against research, questioning, information production (Korkmaz et al., 2011). In this context, the study of the attitudes of teachers, students and academicians towards academic research in general has taken place in the field of study. The researchers emphasized the lack of scientific research and attitude studies of teachers and developed new scales for the field literature (Korkmaz et al., 2011; İlhan, Şekerci, Sözbilir and Yildırım, 2014; Öztürk, 2010; Everton, Galton and Pell, 2000). Besides, studies examining students' attitudes towards research are also available (Papanastasiou, 2005; Bolin, Lee, GlenMaye and Yoon, 2012; Kalayc1, 2008). In addition to teachers and students, studies 
examining academicians' attitudes towards research have also been found in the literature. Wood (1990) pointed out that "personal character", "research area", "money", "equipment", "support staff", "colleague and working environment", "graduate education department and working environment", "number of PhD students", "teaching and administrative demands" and "duties time" factors affect the research performance of academic staff. Zhang (2019) conducted a study in China, identified academic staff working at different levels at 16 different universities, such as Professors, Associate Professors, Assistant Professors and Lecturers, as a sample of the research. The researcher has examined the effect of "promotion", "material reward", "staff seeking", "performance evaluation", "peer and social recognition", "social respect" external factors and "sense of accomplishment", "interest and curiosity", "contributing to society", "sense of responsibility", "academic follow-up" and " independence" intrinsic factors on motivation. The researcher found that all other factors except for "material reward" are effective motivation factors that lead academics to conduct research. Moreover, the researcher examined the effect of "self-competence", "age", "social networking", "research support", "teaching burden", "faculty size" and "culture" factors on the productivity of academicians at different levels. According to the results of the research, it has been emphasized that other factors outside the age affect the productivity of academicians.

In recent years, governments have assumed that economic development can be achieved through knowledge-based growth and have developed their policies in this direction. For this reason, universities are supposed that information is produced effectively, research and development findings are freely shared among academicians, and science-based knowledge is transferred from academia to industry and contributes to the spread of innovation locations. Countries try to regulate their economic growth around these policies and transform universities into centers that make science and produce technology worldwide. According to the global innovation index's 2020, high-income countries lead the ranking (Cornell University, INSEAD, and WIPO, 2020). In order to increase the innovation levels of low and middle income countries success, universities need to develop project culture by improving entrepreneurship and innovation performance and increasing the number of projects for research and development in line with strategic priorities and plans. In that respect, Project Management Offices in the Universities have an important role to enhance project culture within the academicians. The positive attitude that academicians will develop towards project making will greatly increase the ability of universities to produce projects. In this context, as a general answer of the research question "What are the factors affecting the attitudes of academicians towards project development for innovation management?" has been sought. With this research question, it has been clarified that the obstacles to the development of projects by academicians and what are the factors that affect the attitudes of academicians towards project development in a positive and negative way. It is envisaged that identification of the factors affecting academicians' attitudes towards 
project development leads to rethink the obstacles of universities to become targeted innovative and entrepreneurial, and produce projects that support the country's economy and solve social problems by increasing their potential. With dissemination of project culture in universities, the obstacles to many benefits that can be achieved such as enhancement on the capability of innovation, development of new products, processes and technologies, increasing the country's competitiveness strength, supporting the career development of academicians, increasing interaction between international and inter-sectoral interaction will have been clarified.

\section{METHOD}

\section{Ethic}

The scale developed for this study was conducted in Turkey. The ethical document required for the study was approved by the Atatürk University Social and Human Sciences Ethics Committee and the relevant document is given below. In this study, attention has been paid to research and publication ethics. In addition, participants signed a voluntary consent form. 


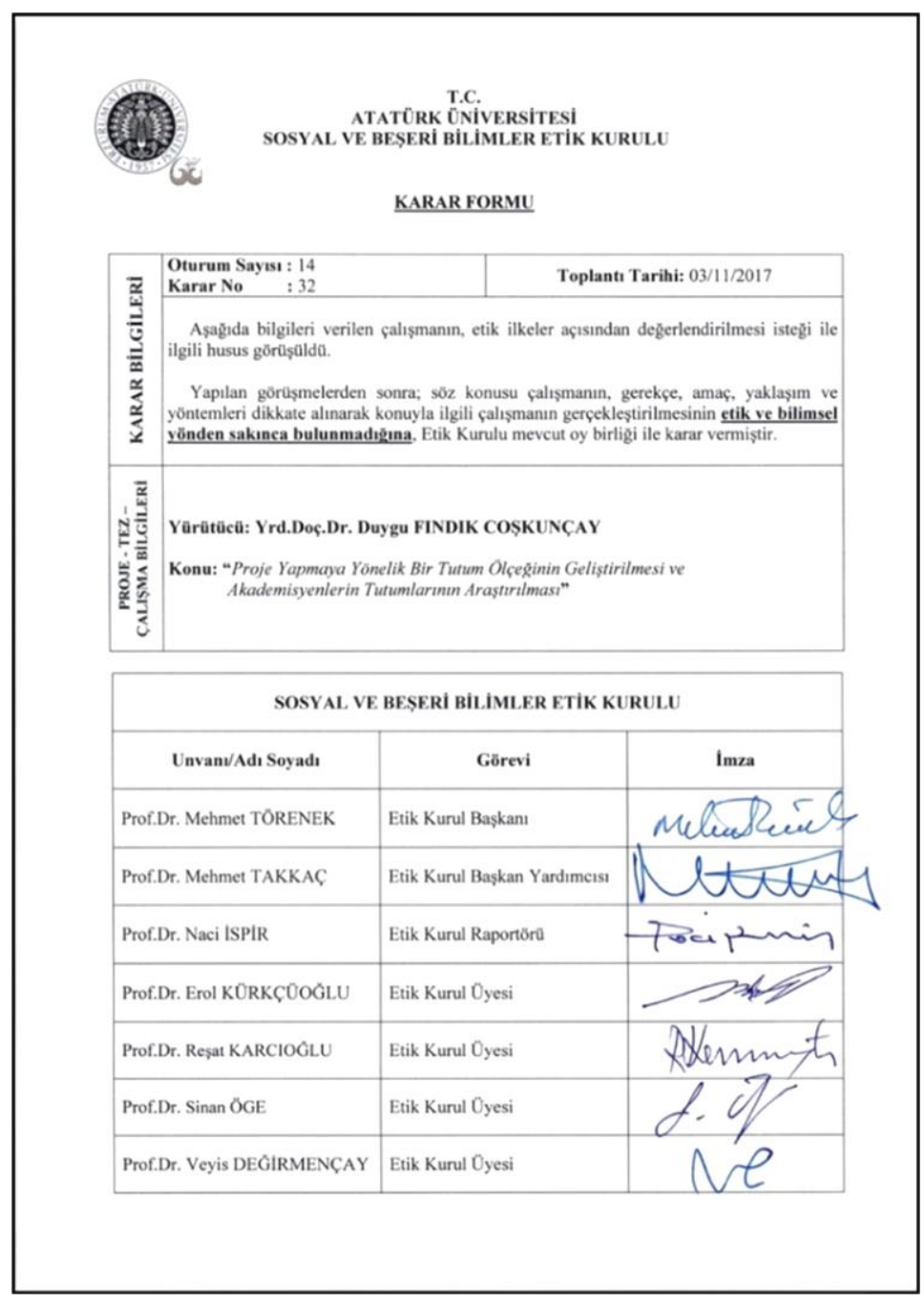

Figure 1: Ethics Committee Approval

\section{Process}

The research design of this study, in which experimental study and case study will be carried out together, is the 'exploratory sequential design'. According to Creswell and Clark (2014), the exploratory design prioritizes the collection and analysis of qualitative data, and research begins with this. Through the discovered results, the researcher begins to implement quantitative research and tests or improves primary results. It then explains how it builds quantitative data on qualitative data.

In this study, "30 Projects \& 30 Mentors one-on-one project writing training" was organized by the Project Management Office. As Sergeeva and Ali (2020) stated that Project Management Offices increase innovative capabilities of the owner and operator organizations. Therefore, the training activities towards project management is so important for academicians to increase their project writing capabilities. In the training carried out, 31 academicians with project ideas were given theoretical and practical project writing training. 
Academicians have been given theoretical background on "What is an R\&D project?", "Ethical Rules in Project Management", "Subject Scope Literature Summary", "Purpose, Original Value \& Widespread Impact", "Feasibility (Method)" and "Panel Process in Tubitak" for one day. Within the scope of this training program, academicians with external fund-based project experience have been selected as mentors. After the mentor and the academician matching was made according to the research areas, a hands-on training program lasting 11 weeks was conducted. Within the scope of applied education, mentors gave theoretical information to the academicians about "Title and Project Summary", "Purpose and Objectives", "Subject, Scope and Literature Summary", "Original Value", "Method", "Project Management, Team and Research Opportunities" and "Widespread Impact" and gave one-to-one support to the project writing process of academicians. Qualitative narratives on the attitudes of academicians towards project construction were collected and the factors affecting them were analyzed through semi-structured interviews applied at the beginning and end of the educational program. The result categories found are considered as formats and a quantitative tool: "attitude scale for project development" has been developed. As a limitation, the semistructured interviews were conducted with the academicians from the Atatürk University. In order to extend the scope of the factor definitions, the interviews could be performed with the academicians of other universities.

\section{Data collection tools}

The applied scale consists of two parts. In the first part, demographic information about gender, academic degree, project experiences, roles in the projects and the fund source supporting their projects is obtained. In the second part, a 5 point Likert scale $(1=$ Absolutely disagreed, 5 = Absolutely agree) developed with 36 items to measure the factors of the proposed research model is used. Factor definitions and scale items are given in Table 1.

Table 1: Factor Definitions and Scale Items

\begin{tabular}{|c|c|c|c|c|}
\hline Factor & Factor Definition & Expression Code & Scale Items & Reference \\
\hline \multirow[t]{2}{*}{$\begin{array}{l}\text { Expected } \\
\text { External } \\
\text { Awards (EEA) }\end{array}$} & \multirow[t]{2}{*}{$\begin{array}{l}\text { The degree to which } \\
\text { one believes that one } \\
\text { will benefit from } \\
\text { external rewards and } \\
\text { incentives to develop } \\
\text { projects. }\end{array}$} & EEA1 & $\begin{array}{l}\text { The financial } \\
\text { income I will } \\
\text { receive in return } \\
\text { for my project } \\
\text { development (e.g. } \\
\text { monthly financial } \\
\text { support, Project } \\
\text { Incentive Bonus) is } \\
\text { important to me. }\end{array}$ & \multirow[t]{2}{*}{$\begin{array}{l}\text { (Bock, Zmud, Kim } \\
\text { and Lee, 2005) }\end{array}$} \\
\hline & & EEA2 & $\begin{array}{l}\text { When I develop a } \\
\text { project, I am } \\
\text { motivated by an } \\
\text { improvement in }\end{array}$ & \\
\hline
\end{tabular}




\begin{tabular}{|c|c|c|c|c|}
\hline & & & $\begin{array}{l}\text { my social rights } \\
\text { such as lodging. }\end{array}$ & \\
\hline & & EEA3 & $\begin{array}{l}\text { The financial } \\
\text { support policy } \\
\text { implemented by } \\
\text { the university in } \\
\text { return for my } \\
\text { project } \\
\text { development is } \\
\text { important to me. }\end{array}$ & \\
\hline \multirow{4}{*}{$\begin{array}{l}\text { Perception of } \\
\text { Self Worth (SW) }\end{array}$} & \multirow{4}{*}{$\begin{array}{l}\text { A degree of positive } \\
\text { cognition based on the } \\
\text { feeling of personal } \\
\text { contribution to the } \\
\text { university and society } \\
\text { by developing a } \\
\text { project. }\end{array}$} & SW1 & $\begin{array}{l}\text { When I develop a } \\
\text { project, I think I } \\
\text { am useful to the } \\
\text { target audience }\end{array}$ & \multirow[t]{4}{*}{ (Bock et al., 2005) } \\
\hline & & SW2 & $\begin{array}{l}\text { I provide new } \\
\text { research } \\
\text { opportunities to } \\
\text { the university by } \\
\text { developing } \\
\text { projects. }\end{array}$ & \\
\hline & & SW3 & $\begin{array}{l}\text { I can increase } \\
\text { productivity at the } \\
\text { university by } \\
\text { developing a } \\
\text { project. }\end{array}$ & \\
\hline & & SW4 & $\begin{array}{l}\text { By developing a } \\
\text { project, I help my } \\
\text { university to rank } \\
\text { in the success } \\
\text { indexes (e.g. } \\
\text { Entrepreneurial } \\
\text { Innovative } \\
\text { University index). }\end{array}$ & \\
\hline \multirow{3}{*}{$\begin{array}{l}\text { Social Norm } \\
(\mathrm{SN})\end{array}$} & \multirow[t]{3}{*}{$\begin{array}{l}\text { Social pressure on } \\
\text { people from the social } \\
\text { environment to } \\
\text { perform such } \\
\text { behavior. }\end{array}$} & SN1 & $\begin{array}{l}\text { The university } \\
\text { administration } \\
\text { supports me in } \\
\text { developing } \\
\text { projects }\end{array}$ & \multirow{3}{*}{ (Ajzen, 1991) } \\
\hline & & SN2 & $\begin{array}{l}\text { The academicians } \\
\text { that I care about } \\
\text { think I need to } \\
\text { develop a project }\end{array}$ & \\
\hline & & SN3 & $\begin{array}{l}\text { Academicians who } \\
\text { influence my } \\
\text { academic } \\
\text { development } \\
\text { encourage me to } \\
\text { develop projects. }\end{array}$ & \\
\hline $\begin{array}{l}\text { Perceived Self- } \\
\text { Efficacy (SE) }\end{array}$ & $\begin{array}{l}\text { The degree to which } \\
\text { academics believe in }\end{array}$ & SE1 & $\begin{array}{l}\text { I believe that I can } \\
\text { achieve most of the }\end{array}$ & (Bandura, 1986) \\
\hline
\end{tabular}




\begin{tabular}{|c|c|c|c|c|}
\hline & $\begin{array}{l}\text { their own competence } \\
\text { to develop Project }\end{array}$ & & $\begin{array}{l}\text { goals I have set } \\
\text { when developing a } \\
\text { project. }\end{array}$ & \\
\hline & & SE2 & $\begin{array}{l}\text { I am confident that } \\
\text { I will overcome the } \\
\text { difficulties I will } \\
\text { face when } \\
\text { developing a } \\
\text { project. }\end{array}$ & \\
\hline & & SE3 & $\begin{array}{l}\text { I think that, I can } \\
\text { achieve important } \\
\text { results by } \\
\text { developing a } \\
\text { project. }\end{array}$ & \\
\hline & & SE4 & $\begin{array}{l}\text { I can work } \\
\text { effectively in } \\
\text { different tasks } \\
\text { when developing } \\
\text { projects. }\end{array}$ & \\
\hline & & SE5 & $\begin{array}{l}\text { Even if the project } \\
\text { development } \\
\text { process is difficult, } \\
\text { I can perform quite } \\
\text { well. }\end{array}$ & \\
\hline \multirow{3}{*}{ Reputation (R) } & \multirow[t]{3}{*}{$\begin{array}{l}\text { The degree to which } \\
\text { one believes that } \\
\text { one's reputation will } \\
\text { increase through } \\
\text { project development. }\end{array}$} & $\mathrm{R} 1$ & $\begin{array}{l}\text { Developing a } \\
\text { project leads me to } \\
\text { gain respect in the } \\
\text { academic } \\
\text { community. }\end{array}$ & \multirow{3}{*}{$\begin{array}{c}\text { (Hsu and Lin, } \\
\text { 2008) }\end{array}$} \\
\hline & & $\mathrm{R} 2$ & $\begin{array}{l}\text { Developing } \\
\text { projects will } \\
\text { increase my } \\
\text { reputation in the } \\
\text { sight of my } \\
\text { students. }\end{array}$ & \\
\hline & & R3 & $\begin{array}{l}\text { Developing a } \\
\text { project will } \\
\text { increase my } \\
\text { reputation in the } \\
\text { sight of university } \\
\text { administration. }\end{array}$ & \\
\hline \multirow[b]{2}{*}{ Anxiety (A) } & \multirow{2}{*}{$\begin{array}{l}\text { A wide range of } \\
\text { anxiety, intrusive } \\
\text { thoughts, mental } \\
\text { distraction, tensions } \\
\text { and the degree of } \\
\text { physiological arousal } \\
\text { experienced by the } \\
\text { person when } \\
\text { developing project. }\end{array}$} & A1 & $\begin{array}{l}\text { Project } \\
\text { development } \\
\text { (idea) makes me } \\
\text { nervous. }\end{array}$ & \multirow[b]{2}{*}{ (Zeidner, 1990) } \\
\hline & & $\mathrm{A} 2$ & $\begin{array}{l}\text { I am concerned } \\
\text { about the } \\
\text { correspondence I } \\
\text { will encounter } \\
\text { during the project }\end{array}$ & \\
\hline
\end{tabular}




\begin{tabular}{|c|c|c|c|c|}
\hline & & & $\begin{array}{l}\text { development } \\
\text { process. }\end{array}$ & \\
\hline & & A3 & $\begin{array}{l}\text { The excess of } \\
\text { bureaucratic } \\
\text { procedures in the } \\
\text { project } \\
\text { development } \\
\text { process causes me } \\
\text { to be stressed. }\end{array}$ & \\
\hline & & $\mathrm{A} 4$ & $\begin{array}{l}\text { Project } \\
\text { development } \\
\text { (idea) makes me } \\
\text { feel insecure. }\end{array}$ & \\
\hline \multirow{4}{*}{$\begin{array}{l}\text { Team } \\
\text { Interaction (TI) }\end{array}$} & \multirow{4}{*}{$\begin{array}{l}\text { The ability of a } \\
\text { person to form a } \\
\text { work team and the } \\
\text { degree of individual } \\
\text { willingness to } \\
\text { continue working } \\
\text { with his own team as } \\
\text { well as other teams } \\
\text { while developing a } \\
\text { project. }\end{array}$} & TI1 & $\begin{array}{l}\text { I enjoy the } \\
\text { experience of } \\
\text { collaborative } \\
\text { work. }\end{array}$ & \multirow{4}{*}{$\begin{array}{l}\text { (Gardner and } \\
\text { Korth, 1998) }\end{array}$} \\
\hline & & TI2 & $\begin{array}{l}\text { Group work } \\
\text { increases my } \\
\text { creativity. }\end{array}$ & \\
\hline & & TI3 & $\begin{array}{l}\text { I feel better } \\
\text { psychologically in } \\
\text { group work. }\end{array}$ & \\
\hline & & TI4 & $\begin{array}{l}\text { I think I can get } \\
\text { more successful } \\
\text { results with group } \\
\text { work. }\end{array}$ & \\
\hline \multirow{3}{*}{ Justice (J) } & \multirow[t]{3}{*}{$\begin{array}{l}\text { The perception that } \\
\text { fund- institution } \\
\text { practices are fair and } \\
\text { not be arbitrary or } \\
\text { capricious in respect } \\
\text { to project } \\
\text { development. }\end{array}$} & $\mathrm{J} 1$ & $\begin{array}{l}\text { When I send my } \\
\text { project to the } \\
\text { funding } \\
\text { organization; I } \\
\text { believe that the } \\
\text { project evaluation } \\
\text { process will be } \\
\text { accurate, honest } \\
\text { and realistic. }\end{array}$ & (Bock et al., 2005) \\
\hline & & $\mathrm{J} 2$ & $\begin{array}{l}\text { I think that the cost } \\
\text { items and total } \\
\text { budget assessment } \\
\text { that I wrote in the } \\
\text { project budget will } \\
\text { be done fairly. }\end{array}$ & \\
\hline & & $\mathrm{J} 3$ & $\begin{array}{l}\text { I believe that } \\
\text { additional time } \\
\text { and additional } \\
\text { budget requests } \\
\text { for my project will } \\
\text { be properly } \\
\text { evaluated. }\end{array}$ & \\
\hline \multirow{2}{*}{$\begin{array}{l}\text { Attitude } \\
\text { towards Project } \\
\text { Development } \\
\text { (ATT) }\end{array}$} & \multirow{2}{*}{$\begin{array}{l}\text { The degree of one's } \\
\text { positive feelings } \\
\text { about project } \\
\text { development. }\end{array}$} & ATT1 & $\begin{array}{l}\text { I like to develop } \\
\text { projects. }\end{array}$ & \multirow{2}{*}{$\begin{array}{c}\text { (Ajzen and } \\
\text { Fishbein, 1980) }\end{array}$} \\
\hline & & ATT2 & $\begin{array}{l}\text { The idea of } \\
\text { developing a }\end{array}$ & \\
\hline
\end{tabular}




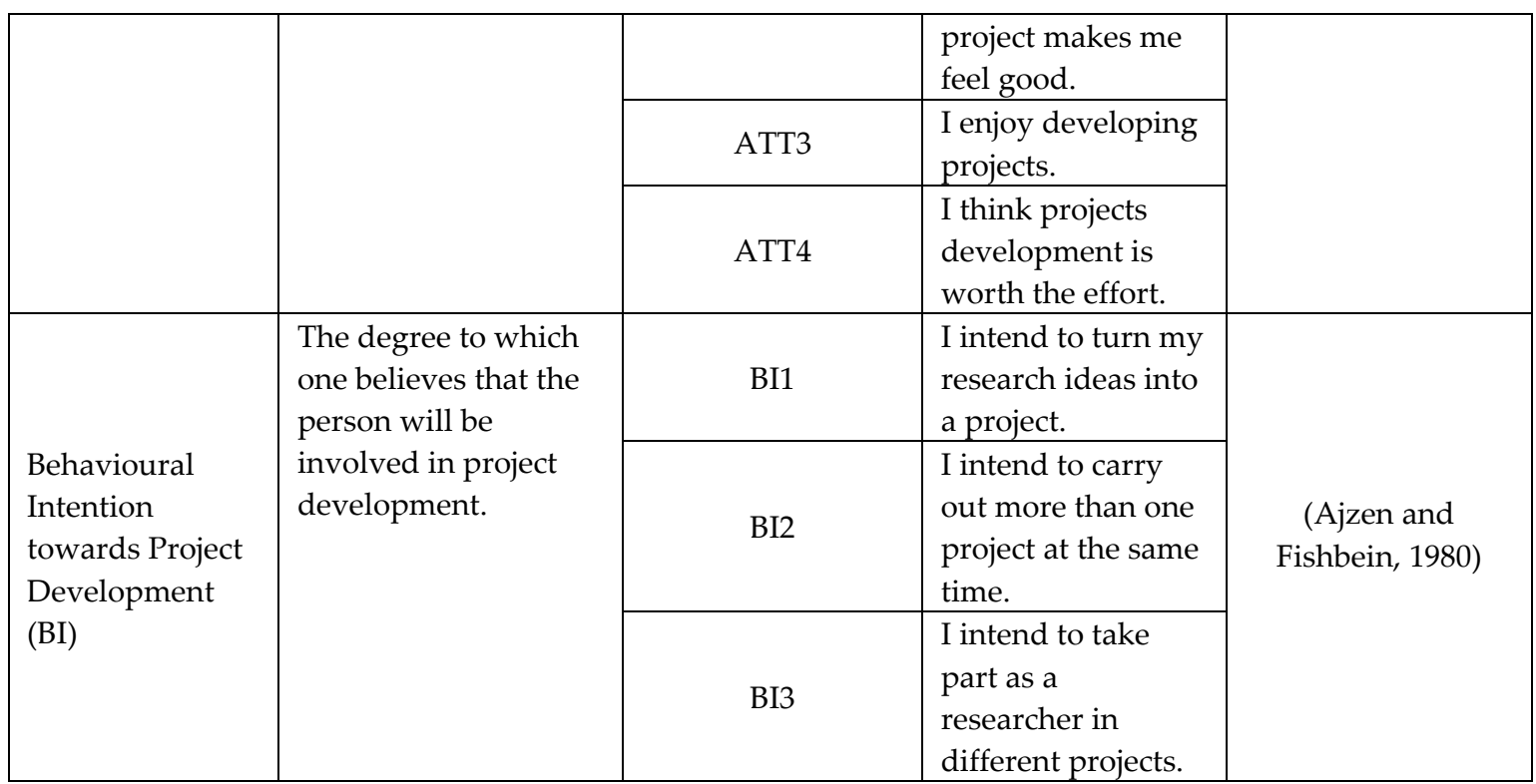

\section{Research Model and Hypothesis}

The effect of "Expected External Awards", "Perception of Self Value", "Social Norm", "Perceived Self-Efficacy", "Reputation", "Anxiety", "Team Interaction", "Justice" factors on "Attitude towards Project Development" and also the effect of "Attitude towards Project Development" on "Behavioural Intention towards Development" was examined within the scope of the structural model presented. In this study, the structural model presented to evaluate attitudes of academicians towards project development is shown in Figure 1.

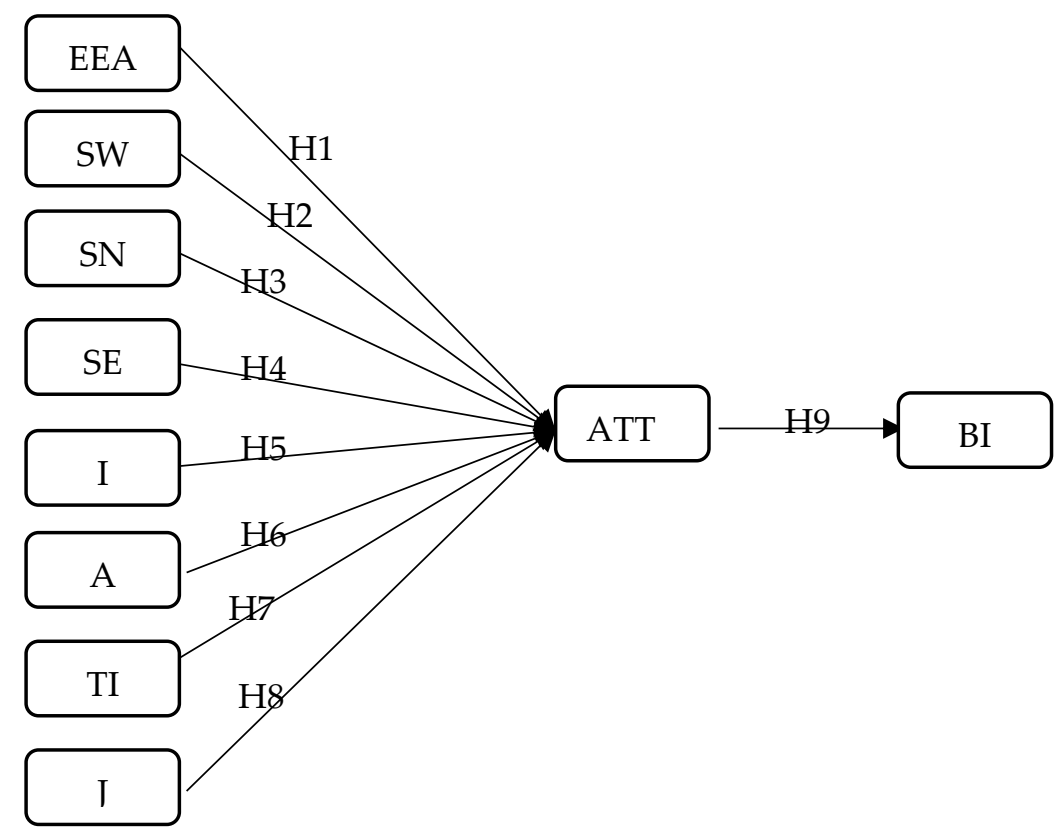

Figure 2: Research Model 
The following hypotheses will be examined within the scope of this model.

H1: EEA affects ATT directly and positively

H2: SW affects ATT directly and positively

H3: SN affects ATT directly and positively

H4: SE affects ATT directly and positively

H5: R affects ATT directly and positively

H6: A affects ATT directly and negatively

H7: TI affects ATT directly and positively

H8: J affects ATT directly and positively

H9: ATT affects BI directly and positively

\section{Sample}

Within the scope of this study, academicians working in a total of 68 universities taking place in seven different regions of Turkey (Eastern Anatolia Region, Central Anatolia Region, Black Sea Region, Mediterranean Region, Aegean Region, South Eastern Anatolia Region and Marmara Region) participated in the study. A total of 590 academicians completed totally the questionnaire. The total participant response rate is $45.57 \%$. In addition, participants were classified in 5 different fields: Basic Sciences (e.g. Biology, Physics, Chemistry), Social and Humanities (e.g. Business, Economy, Tourism, Education), Health Sciences (e.g. Medical Science, Nursing, Pharmacy, Veterinary Medicine) and Engineering Sciences (e.g. Computer Science and Engineering, Electrical Electronics Engineering, Chemical Engineering) according to their fields of study. While being made this classification, the scientific field classifications of ULKABIM, YÖK and TUBITAK were taken into account and the main areas of study of the participants were categorized as given in Table 2. $24.4 \%$ of the participants are working in Basic Sciences, 24.1\% in Social and Humanities, $28 \%$ in Engineering Sciences and $23.4 \%$ in Health Sciences.

Table 2: Research Fields and Numbers of Participants

\begin{tabular}{lc}
\hline Fields & $\begin{array}{c}\text { Participants } \\
(\mathbf{N})\end{array}$ \\
\hline Basic Sciences & 144 \\
\hline Social and Humanity Sciences & 142 \\
\hline Engineering Sciences & 165 \\
\hline Health Sciences & 138 \\
\hline
\end{tabular}




\section{AJIT-e Bilişim Teknolojileri Online Dergisi \\ Academic Journal of Information Tecnology \\ 2021 Spring/Bahar - Cilt/Vol: 12 - Sayı/Issue: 45 \\ doi 10.5824/ajite.2021.02.004.x}

Demographic information of the participants is given in Table 3 in detail. $45 \%$ of the sample is female and $55 \%$ is male. In addition, $27 \%$ of the sample is professor, $21 \%$ is associate professor and $32 \%$ are academicians with the title of assistant professor. $93 \%$ of the participants have project experience. $32 \%$ of the participants were project managers, $33 \%$ were researchers and $11 \%$ were consultants. Furthermore, $45 \%$ of the academicians in the sample group took part in projects funded by Scientific Research Projects in Turkey, 34\% by The Scientific and Technological Research Council of Turkey and 7\% by the European Union.

Table 3: Demographic Information of Participants

\begin{tabular}{|c|c|c|}
\hline \multirow{2}{*}{ Gender } & Female & $\% 45$ \\
\hline & Male & $\% 55$ \\
\hline \multirow{6}{*}{ Academic Degree } & Research Assistant (Master of Science) & $\% 1$ \\
\hline & Research Assistant (Doctorate) & $\% 15$ \\
\hline & Lecturer & $\% 4$ \\
\hline & Assistant Professor & $\% 32$ \\
\hline & Associate Professor & $\% 21$ \\
\hline & Professor & $\% 27$ \\
\hline \multirow[b]{2}{*}{ Project Experience } & Yes & $\% 93$ \\
\hline & No & $\% 7$ \\
\hline \multirow{7}{*}{ Roles in Projects } & Project Manager & $\% 32$ \\
\hline & Consultant & $\% 11$ \\
\hline & Researcher & $\% 33$ \\
\hline & Supervisor & $\% 4$ \\
\hline & Reviewer & $\% 11$ \\
\hline & Scholar & $\% 7$ \\
\hline & No Experience & $\% 2$ \\
\hline \multirow{6}{*}{$\begin{array}{l}\text { Funding } \\
\text { Institutions }\end{array}$} & Scientific Research Projects in Turkey & $\% 45$ \\
\hline & $\begin{array}{l}\text { The Scientific and Technological Research } \\
\text { Council of Turkey }\end{array}$ & $\% 34$ \\
\hline & European Union & $\% 7$ \\
\hline & Ministries of Turkey & $\% 7$ \\
\hline & Associations and agencies & $\% 4$ \\
\hline & Others & $\% 3$ \\
\hline
\end{tabular}

\section{FINDINGS}

\section{Preliminary Analyses}

On the data obtained, the data set was prepared for further analyses to be carried out later by evaluating loss data, contrary (extreme) values and normal distribution assessment (Leech, Barrett and Morgan, 2005; Hair, Black, Babin, Anderson and Tatham, 2006; Gravetter and Wallnau, 2000). No missing data was found in any statements in the data set, so no action 
was taken to edit the missing data. In addition, no extreme value was found in the data set. Therefore, no action has been taken to edit the outlier data. Skewness and Kurtosis values, Kolmogorov-Smirnov and Shapiro-Wilk statistics are used for normality assessment. Skewness and Kurtosis values were taken into account to evaluate the normality distribution of the data set used to measure the factors. West, Finch and Curran (1995) recommend that the skewness value should not be greater than 2 and the kurtosis value should not be higher than 7 to ensure the normal distribution requirement. In line with these values, data can be interpreted as normal. However, Kolmogorov-Simirnov and Shapiro-Wilk statistics and Histogram results show that the data was not normal. Therefore, as an ultimate decision, the assumption was made that the data was not distributed normally.

\section{Factor Analysis and Reliability Analysis}

The factor structure of the data set was examined by exploratory factor analysis. Exploratory factor analysis was performed with maximum likelihood and direct oblimin rotation method; because of the scale items in the data set are related to each other (Field, 2005). Based on the assumptions for the exploratory factor analysis, it was observed that the value of Kaiser-Meyer-Olkin is 0.912 . This value, which should be a minimum of 0.5 , indicates that the number of samples used in the analysis is sufficient for factor analysis (Field, 2005). Bartlett's test of sphericity value $(x 2(630)=9709.424(\mathrm{p}<.001))$ shows that the data set has a significant factor structure.

As a result of the exploratory factor analysis, 9 significant factor structures were obtained with a total variance of $53 \%$. Table 4 shows the factor structures of scale items, factor loads, and Cronbach's alpha reliability values for each factor. SW1, SN1, SE1, SE2 and SE3 were removed from the scale due to their insignificant load or low factor load. In addition, $\mathrm{SN} 2, \mathrm{SN} 3, \mathrm{R} 1, \mathrm{R} 2$ and R3 substances were assumed to belong to a single factor because these items were collected under a single factor with very high factor loads. When the item definitions of SN and R were examined in detail, it was seen that both factors were related to the social perceptions of the participants. So, the clustering of the items related with $\mathrm{SN}$ and $\mathrm{R}$ under the same factor made sense. Moreover, scale materials were renamed and analyses continued with these new nomenclatures.

Cronbach Alpha value ranges from 0 to 1 and, the values between 0.6 and 0.7 has acceptable reliability level in spite of they are low (Hair et al., 2006). The reliability analysis results for the nine factor structures in our data set ranged from 0.613 to 0.872 according to Cronbach's Alpha. In addition, Cronbach's alpha value was .866 for the entire scale. In line with these values, the analysis was continued assuming that each factor structure and the entire scale were generally reliable. 
Table 4: Factor Analysis and Reliability Analysis

\begin{tabular}{llllllllllll}
\hline Item & New & 1 & 2 & 3 & 4 & 5 & 6 & 7 & 8 & 9 & Alpha
\end{tabular}

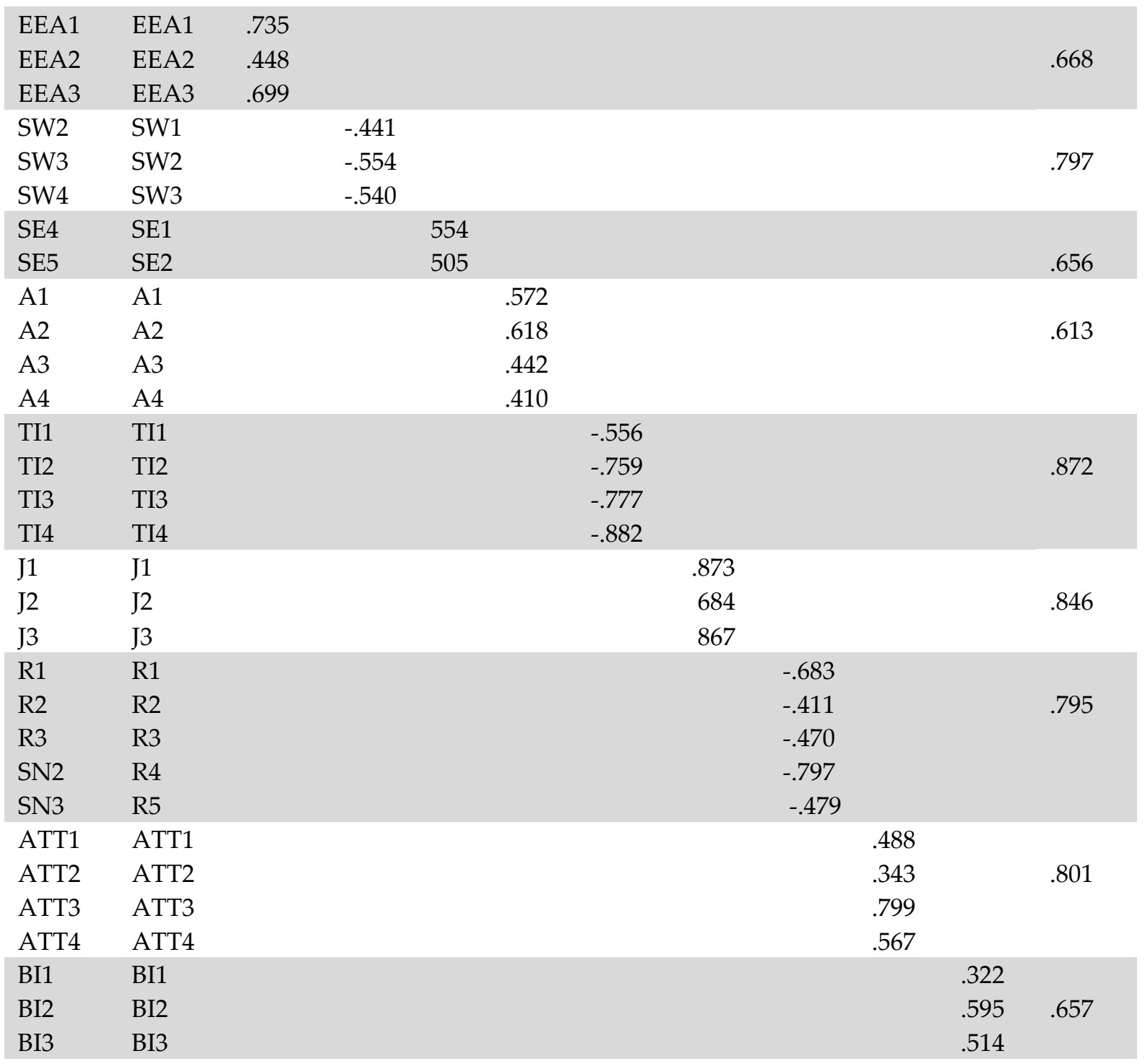

Extraction Method: Maximum Likelihood.

Rotation Method: Oblimin with Kaiser Normalization.

a. Rotation converged in 13 iterations.

\section{Research Model}

Model verification was performed using the SmartPLS 3 program with componentbased structural equality modeling which is partial least squares method (PLS) due to the nonnormal data distribution (Chin, 1998). PLS was used in this study because it is a method suitable for cases where the relationships between theoretical structures are investigated and 
the general nomological network is not well understood (Peng and Lai, 2012). Prior to the evaluation of the structural model, preliminary data analysis was conducted including sample size requirement and outlier detection, missing value analysis, multicollinearity analysis and normality assumption (Hair et al., 2006). The "10 times" rule (Peng and Lai, 2012) was used for the sample size requirement and it was found that the 590 sample sizes used in the study were sufficient to analyze. The research model presented is verified by measurement model and structural model evaluations.

\section{Measurement Model}

The assessment of the measurement model was carried out using the confirmatory factor analysis method to examine the psychometric properties of the measuring instruments and to ensure the front step of the structural model. The measurement model was evaluated by taking into account the convergent validity and the discriminant validity.

The validity of convergence was assessed taking into account factor loading values, average of communality values (Average Variance Extracted - AVE) and composite reliability. Each observed variable must be loaded with a factor load of 0.7 and above to the corresponding implicit variable (Hair et al., 2006). According to factor load values, the question EEA1 and A3 were removed from the measurement model because they did not meet the sufficient factor load value. EEA2 and A2 were not removed from the analysis because they had a relatively small factor load than the expected value. In order to ensure convergence validity, the average communality values of each implicit variable must be greater than 0.5 . According to the results shown in Table 5, all implicit variables met the threshold value. Finally, based on the composite reliability it is seen that all implicit variables had a reliability value above 0.7 . The composite reliability values of implicit variables are given in Table 5. As a result, convergent validity of the measurement model was obtained when the factor loads, average of communality values and composite reliability values were considered.

Table 5: Convergence Validity

\begin{tabular}{|c|c|c|c|c|}
\hline Item Codes & Factor Loads & Composite Reliability & $\begin{array}{l}\text { Average } \\
\text { Extracted }\end{array}$ & Variance \\
\hline EEA1 & .596 & \multirow{3}{*}{.794} & \multirow{3}{*}{$\% 66$} & \\
\hline EEA2 & .659 & & & \\
\hline EEA3 & .943 & & & \\
\hline SW1 & .870 & \multirow{3}{*}{.881} & \multirow{3}{*}{$\% 71$} & \\
\hline SW2 & .847 & & & \\
\hline SW3 & .812 & & & \\
\hline SE1 & .821 & \multirow{2}{*}{.852} & \multirow[t]{2}{*}{$\% 74$} & \\
\hline SE2 & .900 & & & \\
\hline
\end{tabular}


AJIT-e Bilişim Teknolojileri Online Dergisi

Academic Journal of Information Tecnology

2021 Spring/Bahar - Cilt/Vol: 12 - Sayı/Issue: 45

doi) 10.5824/ajite.2021.02.004.x

\begin{tabular}{|c|c|c|c|}
\hline A1 & .758 & \multirow{4}{*}{.783} & \multirow{4}{*}{$\% 54$} \\
\hline A2 & .670 & & \\
\hline A3 & .447 & & \\
\hline A4 & .766 & & \\
\hline TI1 & .777 & \multirow{4}{*}{.912} & \multirow{4}{*}{$\% 72$} \\
\hline TI2 & .871 & & \\
\hline TI3 & .886 & & \\
\hline TI4 & .861 & & \\
\hline J1 & .899 & \multirow{3}{*}{.907} & \multirow{3}{*}{ \%76 } \\
\hline $\mathrm{J} 2$ & .839 & & \\
\hline J3 & .885 & & \\
\hline R1 & .786 & \multirow{5}{*}{.862} & \multirow{5}{*}{$\% 55$} \\
\hline R2 & .714 & & \\
\hline R3 & .692 & & \\
\hline R4 & .816 & & \\
\hline R5 & .718 & & \\
\hline ATT1 & .814 & \multirow{4}{*}{.871} & \multirow{4}{*}{$\% 63$} \\
\hline ATT2 & .700 & & \\
\hline ATT3 & .890 & & \\
\hline ATT4 & .757 & & \\
\hline BI1 & .841 & \multirow{3}{*}{.816} & \multirow{3}{*}{$\% 59$} \\
\hline BI2 & .741 & & \\
\hline BI3 & .732 & & \\
\hline
\end{tabular}

The result of the discriminant validity is given in Table 6. According to the results, it is observed that the square root of the Average of Communality Values for each structure (the values in the diagonal in the table) is greater than the correlation values of all other structures. Therefore, according to Fornell and Larcker (1981), each structure is different from one another.

Table 6: Discriminant Validity

\begin{tabular}{llllllllll}
\hline & J & SE & EEA & BI & R & A & SW & ATT & TI \\
\hline J & 0.875 & & & & & & & & \\
SE & 0.225 & 0.861 & & & & & & & \\
EEA & 0.140 & 0.138 & 0.816 & & & & & & \\
BI & 0.299 & 0.475 & 0.201 & 0.773 & & & & & \\
R & 0.301 & 0.379 & 0.410 & 0.450 & 0.746 & & & & \\
A & -0.101 & -0.186 & 0.104 & -0.157 & -0.045 & 0.740 & & & \\
SW & 0.331 & 0.547 & 0.299 & 0.510 & 0.577 & -0.131 & 0.843 & & \\
ATT & 0.338 & 0.601 & 0.160 & 0.557 & 0.477 & -0.318 & 0.609 & 0.794 & \\
TI & 0.192 & 0.535 & 0.178 & 0.437 & 0.403 & -0.113 & 0.540 & 0.547 & 0.850
\end{tabular}




\section{Structural Model}

The structure of the proposed research model was evaluated by looking at path coefficient values and the statistical validity of the proposed hypotheses was tested. The data set consisting of 590 samples was analyzed by bootstrapping procedure and significance levels between the structures were evaluated. The R square values for ATT and BI factors were 0.563 and 0.310 , respectively. The path coefficient values are shown in the Figure below.

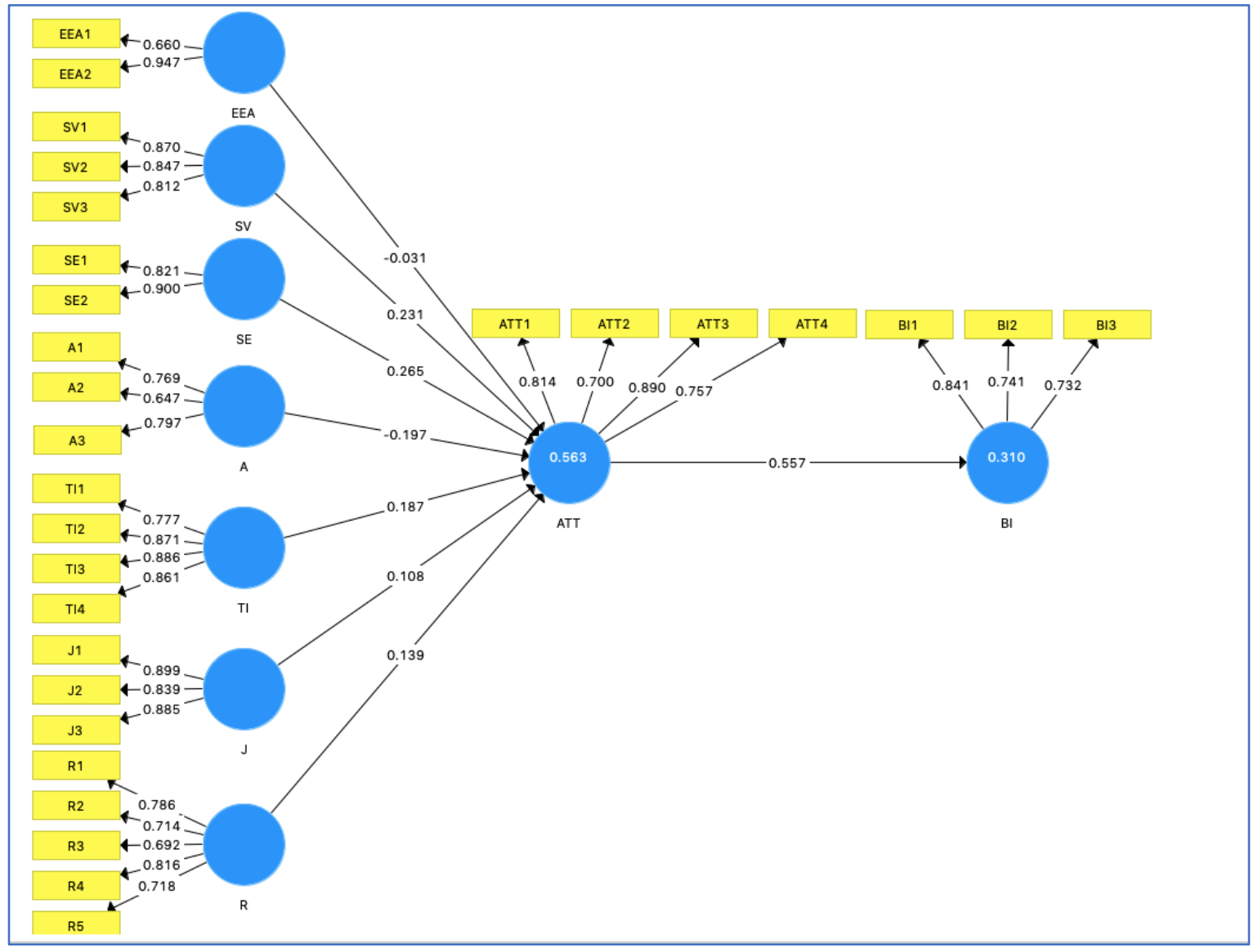

Figure 3: Research Model Findings

According to the results of the structural model (Table 7), there was no significant correlation between EEA and ATT. For this reason, H1 is rejected. It was also suggested with $\mathrm{H} 3$ that there was a direct and significant positive correlation between SN and ATT in the proposed model. However, during the analysis of the exploratory factor, the items belonging to $\mathrm{SN}$ were strongly loaded on the $\mathrm{R}$ factor. Therefore, the $\mathrm{SN}$ factor was removed and $\mathrm{H} 3$ could not be tested. All other hypotheses except for H1 and H3 have been accepted. Strong, direct and positive relationships were found at $\mathrm{p}<0.001$ level among the factors in the $\mathrm{H} 2, \mathrm{H} 4$, $\mathrm{H} 5, \mathrm{H} 7, \mathrm{H} 8$ and $\mathrm{H} 9$ hypotheses. In addition to these, the hypothesis examining the relationship between A and ATT presented with H6 was accepted and it was observed that there was a strong and negative relationship between these two factors at the level of $p<0.001$. 
Table 7: Research Model Hypothesis Results

\begin{tabular}{lllll}
\hline Hi & Relation & T-Value & $\beta$ & Decision \\
\hline H1 & EEA $->$ ATT & 0.868 & -0.031 & Rejected \\
H2 & SW -> ATT & 4.732 & $0.231^{* * *}$ & Accepted \\
H3 & SN $>$ ATT & - & - & Not measured \\
H4 & SE -> ATT & 6.510 & $0.265^{* * *}$ & Accepted \\
H5 & R -> ATT & 3.638 & $0.139^{* * *}$ & Accepted \\
H6 & A -> ATT & 6.218 & $-0.197^{* * *}$ & Accepted \\
H7 & TI -> ATT & 4.277 & $0.187^{* * *}$ & Accepted \\
H8 & J -> ATT & 3.484 & $0.108^{* * *}$ & Accepted \\
H9 & ATT $>$ BI & 15.577 & $0.557^{* * *}$ & Accepted \\
\hline
\end{tabular}

${ }^{*} \mathrm{p}<0.05 ;{ }^{* *} \mathrm{p}<0.01 ;{ }^{* * *} \mathrm{p}<0.001$

\section{DISCUSSION}

Within the scope of this study, factors affecting the attitudes of academicians towards project development were determined; in order to contribute to innovation sustainability. In the discussion section, the relationships acquired within the scope of the research model presented are supported by qualitative interviews conducted. In addition, suggestions are presented for universities and external funding organizations to present what improvements can be done in their policies in the light of the revealed factors; in order to increase the academicians' R\&D Project development capacities. It is foreseen that the findings of the research and the proposed research model will improve attitudes of academicians towards R\&D project development, knowledge-based growth of countries and sustainability in innovation.

In the research model presented, it was observed that the expected external awards had no effect on academicians' attitudes towards project development. Therefore, the hypothesis 1 presented was rejected. As a result of this relationship, it was found that academicians' belief that they would benefit from external rewards and incentives when developing projects had no effect on their attitudes towards project development. The study, conducted by CáceresCarrasco, Santos and Guzmán (2019), also found that the impact of social capital on innovation is not as high as expected. Even if quantitative data show that materialism is not as effective as expected on project development and innovation, result of interviews with academicians showed that financial incentives from funding institutions enable academicians to expand their work and seek answers to more research questions. For instance, as an academician stated during the interviews that "when the cost of the thesis work I planned for my student exceeded the amount given, I had to modify the work and extract some data that we wanted to evaluate." insufficient incentives restrict the work of researchers and narrow the scope of researches. In addition, many academicians stated that factors such as "materiality", "incentive" and "award to academicians who have successfully completed their project" have increased their 
motivation for project development. Although the expected external awards do not give any meaningful results in the research model developed, the interviews conducted with academicians showed that they have expectations towards elimination of space problems for project development and providing fully equipped laboratory environments. In addition, academicians have expectation towards enhancement of the amount of funds to continue the long-termed doctoral dissertation in an effective way. Incentive awards for the successfully completed projects are another expectation of academicians as an external award.

The effect of self-worth perception on the attitudes of academicians towards project development has been examined and it has been shown that the perception of self-value affects the attitude of academicians in a positive and strong way. Therefore, the hypothesis 2 presented within the scope of the research has been accepted. The positive feeling and cognition levels of academicians for their personal contribution to their universities and society by developing projects significantly affect attitudes towards project development. During the interviews, an academic's expression, "I have never doubted to have this desire and perseverance at any stage of my working life because the projects and ideas I have done serve the identity of my country's interest" supports the positive impact of the perception of self-worth on the attitude of academicians, as obtained within the scope of the model. The development of academicians' perceptions of self-worth can be achieved through the contribution they make to institutions and society. At this point, it is important for academicians to be able to identify the needs of the community in creating project ideas. In line with this need, activities aimed at establishing meetings, interviews, panels and working groups where universities can bring academicians together with the community, where problems are discussed, and needs can be identified regulation is important.

In the research model presented, it is aimed to examine the effect of social norms on the attitudes of academicians towards project development within the scope of hypothesis 3. However, the items used in the scale could not significantly form the social norm factor. Therefore, the effect of social norm on the attitudes of academicians towards project development could not be examined within the scope of the model. During the interviews, the question "Do you think that when you are promoted to different academic levels, your motivation for project development has changed over time? What were the changes?" was asked to the academicians and one of them respond as "different projects and research are expected from you after academic rise". Also, one academician respond as "expectations of the target groups" for the question of "What kind of factors motivate you to develop a project?". These explanations are as an evidence for the effect of social impact on the attitude of academicians towards project development. In addition, an academic said during the interviews that "Project development by those around me motivates me to develop projects" reveals that the academician influenced from the project development of the researchers in the 


\section{AJIT-e Bilişim Teknolojileri Online Dergisi \\ Academic Journal of Information Tecnology}

2021 Spring/Bahar - Cilt/Vol: 12 - Sayı/Issue: 45

doi) 10.5824/ajite.2021.02.004.x

social environment. This explanation shows that existence of the academicians who are active in the project development promote the others motivation for the project development.

Perceived self-efficacy has been shown to positively and strongly affect academicians' attitudes towards project development. The hypothesis 4 presented in this context is accepted. This result has shown that academicians' degree of belief in their proficiency and knowledge levels in developing projects strongly affects their attitudes towards project development. During the interviews, it was observed that the academicians' lack of foreign language and insufficient knowledge about project writing made the academics nervous. In addition, an academic working in the field of health gave a statement during the interviews, "So far I have not prepared an external fund-based research and development project. I didn't believe I could handle this kind of project because I am working in a department with a high patient potential and a lack of faculty members. However, the mentor-supported training program motivated me.". It is possible to observe the contribution of the mentor-supported project writing training program to the self-efficacy of the academician and the positive effect of the self-efficacy perception of the academician on the project development attitude. Furthermore, the academicians stated that due to the insufficient number of academicians in the relevant departments and their intensive course loadings, they had difficulty to find enough time for project development and scientific research. At this point, it is important for universities to make improvements in their policies in a way that reduces academicians' course loads and saves them enough time to conduct scientific research.

Within the scope of the model, the impact of reputation on the attitude of academicians towards project development was examined and it was observed that the reputation affects attitude positively and strongly. In this context, hypothesis 5 has been accepted. According to this result, the belief that academicians will increase their reputation through project development positively affects their attitudes towards project development. In the qualitative interviews conducted, the expression given by an academician "it is important for me to increase my potential to publish in quality indexes by developing a project and thus to increase my visibility in the academic community." shows his belief on the positive contribution of the project development to his reputation. In addition, another academician's statement "developing successful projects will increase my reputation in the sight of students" reveals the views of the academician about the positive contribution of the project development to their reputation.

The impact of anxiety on the attitude of academicians towards project development was examined. According to the results obtained, anxiety affects academicians' attitudes towards project development in a negative and strong way. In this context, hypothesis 6 has been accepted. The anxiety, tension and physiological arousal (sweating, contraction, increase 
in heart rate, etc.) caused by the idea of project development and project development process in academicians affect academicians' attitude towards project development negatively. In the qualitative interviews conducted, an academician's statement of "the failure of experiments in the project to reach the expected results, zero withdrawals and the waste of all effort and money make me nervous" clearly demonstrates that the idea and process of developing project create anxiety for the academician. Furthermore, during the interviews, it was observed that some of the factors mentioned increased the anxiety levels of academicians. For instance, the reasons such as, the concern about not being able to complete the project carried out by academics for various reasons, the anxiety of not achieving the targeted goal of the project, the feasibility of the project, the thoughts on whether the results will be effective, not knowing how the proposal and reports were prepared, the possibility that the project was not accepted by the funding body, not having enough time to carry out the project, and the inability to understand the project's ideas by the funding organization have been observed to raise academicians' anxiety levels.

The effect of team interaction on academicians' attitudes towards project development has been examined and it has been shown that team interaction positively and strongly affects the attitude of academicians. Therefore, the hypothesis 7 presented in the study was accepted. With this result, the potential of academicians to form working teams, their potential to collaborate with their own team, different people and working groups have a positive effect on the attitudes of academicians towards project development. The statements given by academicians during the interviews reveal the academicians' perceptions of teamwork. An academic's statement shows how important teamwork is for him; "the reliable team, interdisciplinary colleagues, the continuity of the scholars who will take the laboratory work that will take this job as much as you do motivate me in developing the project". Another academician's statement, "teammates adoption of the project and the continuity of the scholars are important for me" also reveals the importance of team interaction for the academician. Again, with the expression given by an academician, the positive perception of teamwork emerges; "I think multidisciplinary work within the university is very important. I have faith that if people from different disciplines came together from time to time, everyone puts forward what can they do and the idea gymnastics were done, we would have done some really amazing work. Joint congresses can also be held. Science festivals covering the whole university can be organized". The anxiety created by an inactive team interaction in another academician is evident in the academician's speech; "While our potential increased in terms of knowledge and Project topics with the academic rising, the issue of finding teams and qualified staff has become very difficult. While the number of assistants decreased rapidly, the number of students increased at the institute. However, this increased only in number, while the number of students who would take it to the end fell rapidly. In fact, the number of students who appear above a teacher has increased to 10, while the number of students with 
continuity cannot be even 2 at most. While the students are on the list, in reality too many students working in other cities who don't even exist. It seems impossible for me to form a group to carry out this project."

In the research model, the effect of justice on academicians' attitudes towards project development was examined and it was found to have a positive and strong impact on the attitude. The hypothesis 8 presented in this context is accepted. The perception of academicians that the funding institutions applied to are fair and do not make arbitrary decisions positively affect the attitudes of academicians towards project development. As a result of the interviews, the negative perception of the academicians about the fair evaluation of the projects by funding organizations is also noteworthy. For instance, during the interview, an academic expressed his perception that external funding sources are not very reliable in terms of justice; " It would be more beneficial if funding agencies being more objective and they would evaluate what was written rather than who wrote the projects. Universities generally behave fairly because the projects developed are considered a measure of success for universities. But in my opinion, external funding sources are more capricious and detailed about these issues." In the qualitative interviews conducted, academicians expressed their negative opinions about the fact that the names were taken into consideration during the evaluation of the projects, that the bilateral relations could be effective and that the funding institutions did not have a fair scientific evaluation system. Academicians have emphasized that the unfair evaluations made by the funding sources will make them nervous about project development. Despite the negative perceptions of academicians towards the funding institutions at the point of justice, their perception towards the sources of funding will be fair is also draw attention. For instance, an academic expressed his positive perception that the sources of funds are fair as "I think funding organizations are fair. I think that projects that have potential to contribute to the field are evaluated and supported objectively.". The statement of another academic also demonstrates his positive perception of fairness towards funding organizations; "I want to believe that universities and funding agencies are fair and objective. I have never had a situation to think otherwise, and I hope I don't."

In addition to the impact of the above-mentioned factors on the attitudes of academicians towards project development, the impact of academicians' attitude on the behavioral intentions of project development has also been examined in the scope of research model. As a result of the research, it was found out that the attitude of academicians towards project development had a positive and strong effect on their behavioral intention, that is, their degree of belief that they would act in project development. The hypothesis 8 presented in this context is accepted. During interviews conducted, "I used to do BAP projects in the past. Now, I believe that I should develop larger projects," the statement said, clearly observing the academic's behavioral intent to develop projects from external funds. In this context, 
importance of factors (self-worth perception, perceived self-efficacy, reputation, anxiety, team interaction, justice) is undeniable about academicians take action of project development.

\section{CONCLUSION AND SUGGESTIONS FOR FURTHER WORK}

In the scope of this study, the factors affecting academicians' attitude towards R\&D project development were investigated. It was observed that, perception of self-worth, perceived self-efficacy, reputation, anxiety, team interaction and justice factors directly and significantly affect academicians' attitudes towards project development. It is expected that the results of the study will be a guide for the universities to enhance their politics and increase their R\&D project capability for sustainability in innovation.

The researchers are examining the effects of factors on the attitude of academicians working in different disciplines. In addition to this, the research model should be extended with additional variables to improve the model's prediction power on the attitude (56\% variance) and behavioral intention ( $31 \%$ variance). Besides, further studies with cross-cultural approach is required to increase predictive power of the research model.

\section{REFERENCES}

Ajzen, I. (1991). The theory of planned behavior. Organizational Behavior and Human Processes, 50, 179211.

Ajzen, I., \& Fishbein, M. (1980). Understanding attitudes and predicting behavior. Englewood Cliffs, NJ: Prentice Hall.

Autio, E. (1998). Evaluation of RTD in Regional Systems of Innovation. European Planning Studies, 6(2), 13140.

Bandura, A. (1986). Social foundations of thought and action: A social cognitive theory. Prentice-Hall, Inc.

Bock, G., Zmud, R., Kim, Y., \& Lee, J. (2005). Behavioral Intention Formation in Knowledge Sharing: Examining the Roles of Extrinsic Motivators, Social-Psychological Forces, and Organizational Climate. MIS Quarterly, 29(1), 87-111.

Bolin, B. L., Lee, K. H., GlenMaye, L. F., \& Yoon, D. P. (2012). Impact of research orientation on attitudes toward research of social work students. Journal of Social Work Education, 48(2), 223-243.

Cáceres-Carrasco, F. R., Santos, F. J., \& Guzmán, C. (2019). Social capital, personal values and economic development: effect on innovation. An international analysis. Innovation: The European Journal of Social Science Research, 1-26.

Chin, W. (1998). Commentary: Issues and Opinion on Structural Equation Modeling. MIS Quarterly, 22(1), 7-16.

Cooke, P. (2002). Regional Innovation Systems: General Findings and Some new Evidence from Biotechnology Clusters. The Journal of Technology Transfer, 27(1), 133-45. 


\section{AJIT-e Bilişim Teknolojileri Online Dergisi \\ Academic Journal of Information Tecnology \\ 2021 Spring/Bahar - Cilt/Vol: 12 - Sayı/Issue: 45 \\ doi) 10.5824/ajite.2021.02.004.x}

Creswell, J. W., \& Clark, V. L. P. (2014). Karma yöntem araştırmaları: Tasarımı ve yürütülmesi. Ankara: Anı Press.

Cornell University, INSEAD, and WIPO (2020). The Global Innovation Index 2020: Who Will Finance Innovation? Ithaca, Fontainebleau, and Geneva.

Everton, T., Galton, M., \& Pell, T. (2000). Teachers' perspectives on educational research: Knowledge and context. Journal of Education for Teaching: International Research and Pedagogy, 26(2), 167-182.

Field, A. (2005). Discovering Statistics Using SPSS. Second Edition. London, Thousand Oaks, New Delphi: Sage Publications Ltd.

Fornell, C., \& Larcker, D. (1981). Evaluating Structural Equation Models with Unobservable Variables and Measurement Error. Journal of Marketing Research, 18(1), 39-50.

Gardner, B. S., \& Korth, S. J. (1998). A framework for learning to work in teams. Journal of Education for Business, 74(1), 28-33.

Gravetter, F. J., \& Wallnau, L. B. (2000). Statistics for the Behavioral. Belmont, CA: Wadsworth.

West, G., Finch, J. F., \& Curran, P. J. (1995). Structural equation models with non-normal variables: problems and remedies. R. H. Hoyle, (Ed.), London: Stage.

Hair, J. F., Black, W. C., Babin, B. J., Anderson, R. E., \& Tatham, R. L. (2006). Multivariate data analysis. New Jersey: Pearson Prentice Hall.

Hsu, C. L., \& Lin, J. C. C. (2008). Acceptance of blog usage: The roles of technology acceptance, social influence and knowledge sharing motivation. Information \& Management, 45(1), 65-74.

İlhan, N., Şekerci, A. R., Sözbilir, M., \& Yıldırım, A. (2014). Eğitim Araştırmalarına Yönelik Öğretmen Tutum Ölçeğinin Geliştirilmesi: Geçerlik Ve Güvenirlik Çalışması. Batı Anadolu Ĕ̆itim Bilimleri Dergisi, 4(8), 31-56.

Kalaycl, N. (2008). An Application Related to Project Based Learning in Higher Education Analysis in Terms of Students Directing the Project. Science and Education, 33(147), 85-104.

Korkmaz, Ö., Şahin, A., \& Yeşil, R. (2011). Study of validity and reliability of scale of attitude towards scientific research. Elementary Education Online, 10(3), 961-973.

Leech, N. L., Barrett, K. C., \& Morgan, G. A. (2005). SPSS for Intermadiate Statistics Use and Interpretation. Mahwah, New Jersey, London: Lawrence Erlbaum Associates.

Öztürk, M. A. (2010). An exploratory study on measuring educators' attitudes toward educational research. Educational Research and Reviews, 5(12), 758-769.

Papanastasiou, E. C. (2005). Factor structure of the attitudes toward research scale. Statistics Education Research Journal, 4(1), 16-26. 
Peng, D. X., \& Lai, F. (2012). Using partial least squares in operations management research: A practical guideline and summary of past research. Journal of Operations Management, 30(6), 467-480.

Sergeeva N, Ali S. The Role of the Project Management Office (PMO) in Stimulating Innovation in Projects Initiated by Owner and Operator Organizations. Project Management Journal. 2020;51(4):440-451. doi:10.1177/8756972820919215

Veugelers, R. (2014). The Contribution of Academic Research to Innovation and Growth. Published by Europa Wefare Walth.

Wood, F. (1990). Factors influencing research performance of university academic staff. Higher Education, 19(1), 81-100.

Zeidner, M. (1990). Does anxiety bias scholastic aptitude test performance by gender and sociocultural group? Journal of Genetical Psychology, 150, 175-85.

Zhang, X. (2014). Factors that Motivate Academic Staff to Conduct Research and Influence Research Productivity in Chinese Project 211 Universities. PhD. Dissertation, The University of Canberra, Australia. Accessed on: June 16, 2019. [Online]. Available: http://www.canberra.edu.au/researchrepository/file/0814ee30-680b-401e-b0593905b0b686cc/1/full_text.pdf 